\title{
Hydropower Development Opportunities for Alaska Native Villages
}

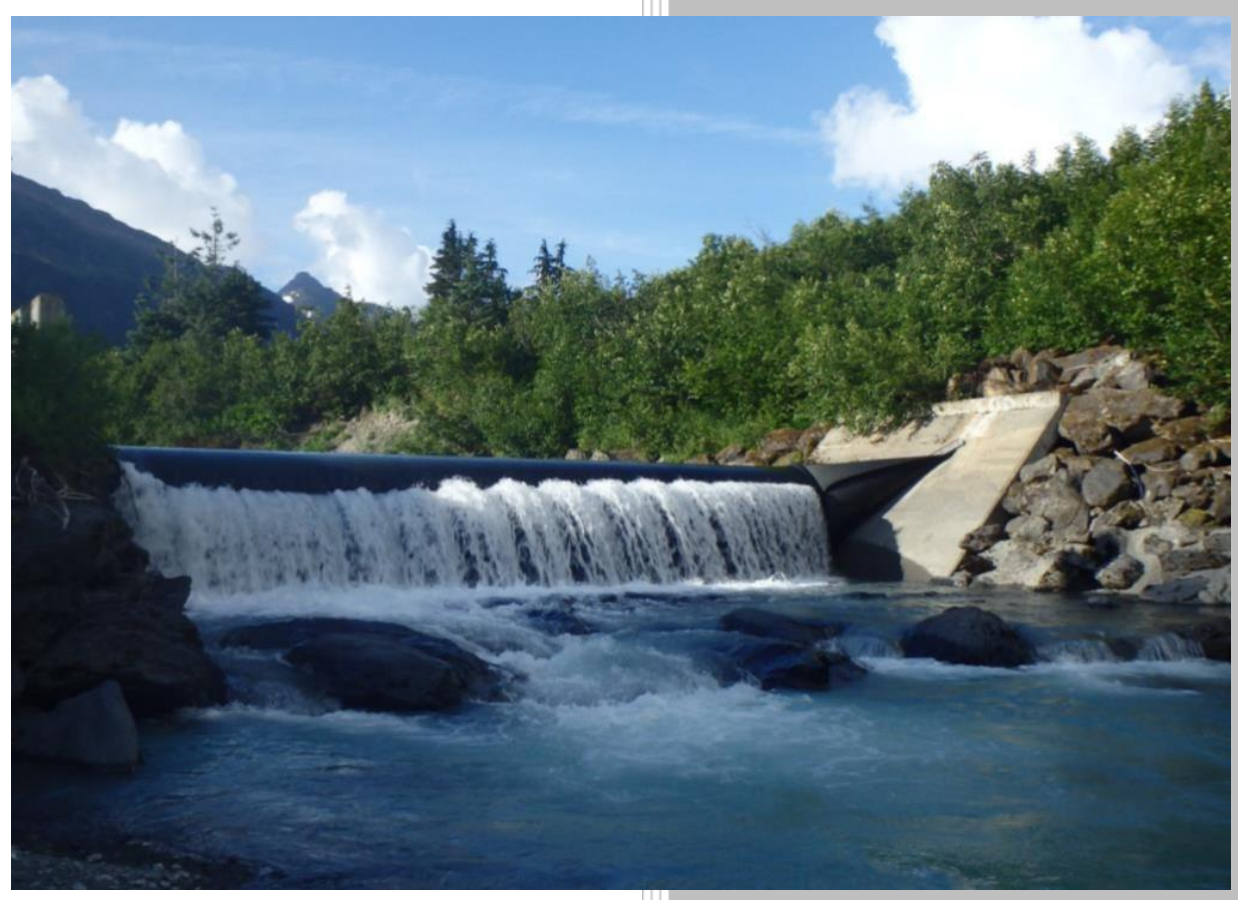

Approved for public release. Distribution is unlimited.
Boualem Hadjerioua

Miles Mobley Scott DeNeale Douglas Ott

September 2018 


\title{
DOCUMENT AVAILABILITY
}

Reports produced after January 1, 1996, are generally available free via US Department of Energy (DOE) SciTech Connect.

Website www.osti.gov

Reports produced before January 1, 1996, may be purchased by members of the public from the following source:

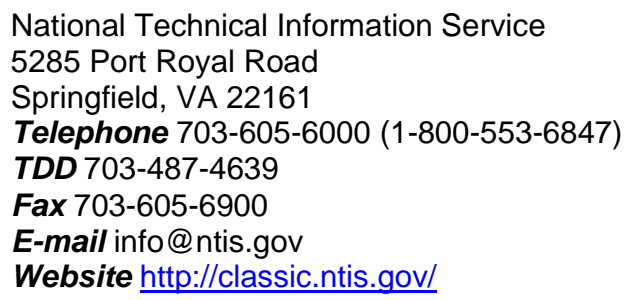

Reports are available to DOE employees, DOE contractors, Energy Technology Data Exchange representatives, and International Nuclear Information System representatives from the following source:

Office of Scientific and Technical Information

PO Box 62

Oak Ridge, TN 37831

Telephone 865-576-8401

Fax 865-576-5728

E-mail reports@osti.gov

Website http://www.osti.gov/contact.html

\begin{abstract}
This report was prepared as an account of work sponsored by an agency of the United States Government. Neither the United States Government nor any agency thereof, nor any of their employees, makes any warranty, express or implied, or assumes any legal liability or responsibility for the accuracy, completeness, or usefulness of any information, apparatus, product, or process disclosed, or represents that its use would not infringe privately owned rights. Reference herein to any specific commercial product, process, or service by trade name, trademark, manufacturer, or otherwise, does not necessarily constitute or imply its endorsement, recommendation, or favoring by the United States Government or any agency thereof. The views and opinions of authors expressed herein do not necessarily state or reflect those of the United States Government or any agency thereof.
\end{abstract}

Cover photo: The Power Creek Hydroelectric project. The picture is courtesy of Cordova Electric Cooperative Inc. 
Environmental Sciences Division

\title{
HYDROPOWER DEVELOPMENT OPPORTUNITIES FOR ALASKA NATIVE VILLAGES
}

Boualem Hadjerioua, Miles Mobley, Scott DeNeale, and Douglas Ott

Date Published: September2018

\author{
Prepared by \\ OAK RIDGE NATIONAL LABORATORY \\ Oak Ridge, TN 37831-6283 \\ Managed by \\ UT-BATTELLE, LLC \\ For the \\ US DEPARTMENT OF ENERGY \\ under contract DE-AC05-00OR22725
}




\section{CONTENTS}

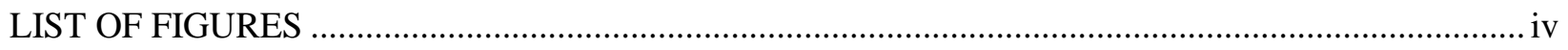

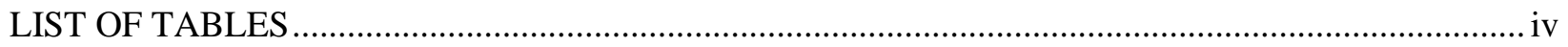

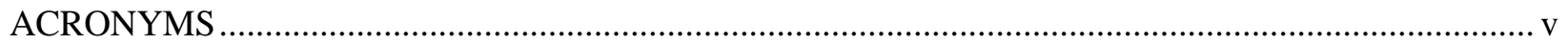

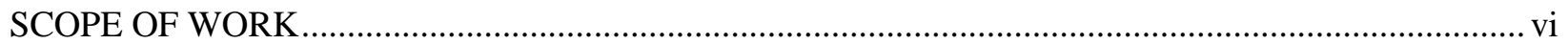

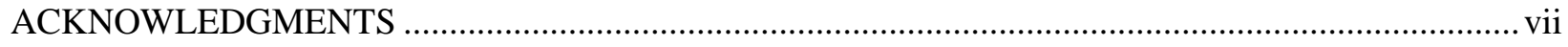

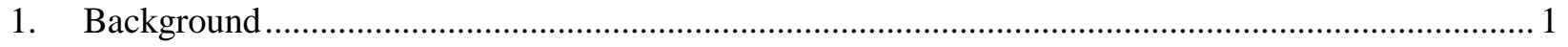

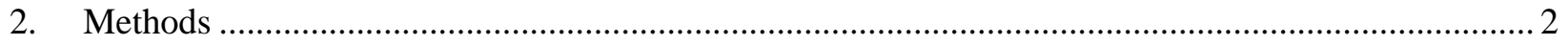

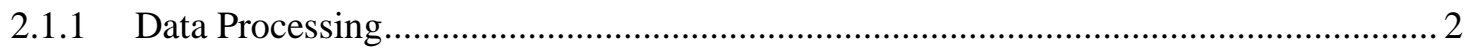

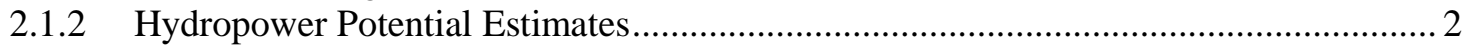

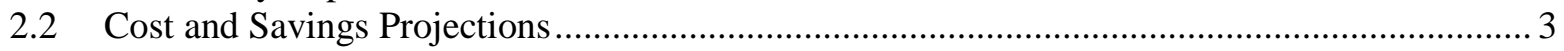

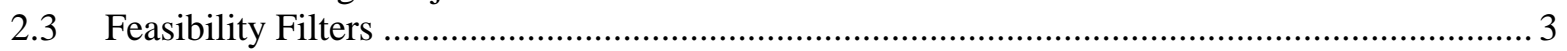

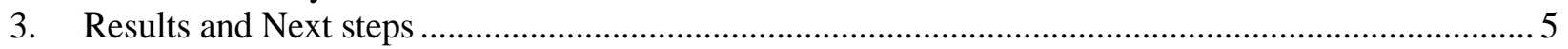

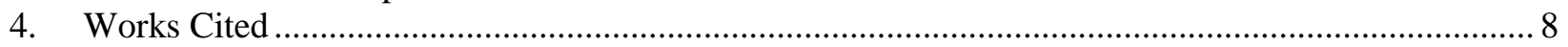




\section{LIST OF FIGURES}

Figure 1. Feasible Hydropower Potential and Native Village Locations.............................................. 1

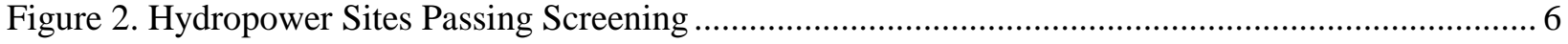

\section{LIST OF TABLES}

Table 1. Villages and Sites Meeting All Filter Criteria ....................................................................... 7 


\section{ACRONYMS}

$\begin{array}{ll}\text { AEA } & \text { Alaska Energy Authority } \\ \text { BIA } & \text { Bureau of Indian Affairs } \\ \text { DOE } & \text { Department of Energy } \\ \text { EIA } & \text { Energy Information Administration } \\ \text { FERC } & \text { Federal Energy Regulatory Commission } \\ \text { FY } & \text { Fiscal Year } \\ \text { kW } & \text { Kilowatt } \\ \text { kWh } & \text { Kilowatt-hour } \\ \text { MW } & \text { Megawatt } \\ \text { MWh } & \text { Megawatt-hour } \\ \text { NSD } & \text { New Stream-reach Development } \\ \text { ORNL } & \text { Oak Ridge National Laboratory } \\ \text { PCE } & \text { Power Cost Equalization Program } \\ \text { PV } & \text { Present Value } \\ \text { USACE } & \text { U.S. Army Corps of Engineers }\end{array}$




\section{SCOPE OF WORK}

This report consolidates efforts among Oak Ridge National Laboratory (ORNL), the United States Department of Energy's (DOE) Office of Indian Energy Policy and Programs, and the Alaska Energy Authority (AEA) to evaluate opportunities for hydropower development among 171 Alaska Native villages.

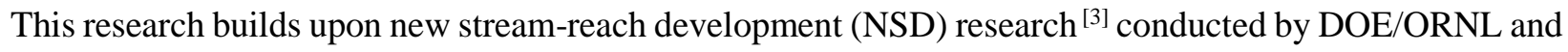
geospatial modelling provided by the Bureau of Indian Affairs (BIA) ${ }^{[2]}$. Based on that information, ORNL has developed a model that evaluates village diesel (gallons) consumption, cost, price per gallon, and kilowatt-hours produced and purchased ${ }^{[4]}$, in conjunction with the past analyses of DOE and BIA, to identify potential benefits of diesel offset from hydropower development on a yearly and 50-year (assumed hydro project lifespan) basis.

To evaluate opportunities for hydropower development sites within untapped stream-reaches in Alaska, seven filters were applied to the data, three static and four dynamic. The three static filters are designed to exclude areas that are already serviced by hydropower, too far from a project site, or require underwater transmission cables. The four dynamic filters incorporate user defined values for maximum latitude, transmission distance, minimum population and diesel usage offset percentage. For the purpose of this discussion, the model's dynamic filters have been assigned default values, however these values may be adjusted to identify areas for NSD that exceed the parameters of the default values, and discussion herein.

After applying these seven filters, the model identified eleven Alaska villages as potential candidates for further analysis on hydropower development. To meet the energy demand of these villages, hydropower projects could be developed to provide Eleven sites can best meet village energy demand with a combined usable capacity of $1.25 \mathrm{MW}$ and 5,488 MWh of annual power generation. Without considering village energy demand, these eleven sites have a combined technical capacity of $2.95 \mathrm{MW}$ and annual generation of 12,934 MWh based on ORNL's previous 2014 NSD study. Results indicate that hydropower development in these eleven villages, over an industry standard 50-year operational lifespan, could potentially reduce their total diesel usage by 435,000 gallons per year, which amounts to a present-day value of 50-year diesel savings totaling more than $\$ 57$ million when projecting annually-reported village fuel costs. Additional data collection, reconnaissance studies, and pre-feasibility analyses may provide a more in-depth understanding of the hydropower potential for Alaska Native communities. 


\section{ACKNOWLEDGMENTS}

This research was supported by funding from the US Department of Energy's Office of Indian Energy.

The authors would like to acknowledge and express their appreciation to all the following individuals and programs for their support of this preliminary technical assessment.

\section{US Department of Energy, Office of Indian Energy}

- Lizana Pierce, Deployment Supervisor

- Givey Kochanowski, Alaska Program Manager

- Michael Kuca, Engineer

\section{Alaska Energy Authority (AEA)}

- Daniel Hertrich, AEA Hydroelectric Program Manager

- Samuel Tappen, AEA Assistant Economist

\section{Bureau of Indians Affairs (BIA), Alaska Region}

- Jessica Rodriguez, Cartographer

\section{Oak Ridge National Laboratory}

- Nicole Samu, Geospatial Data Coordinator/Cartographer

- Missy Miller, Administrative Assistant 



\section{BACKGROUND}

Alaska Native communities are affected by high electricity costs due to significant distances between the rural villages, imported diesel delivery by predominately barge or air, and uncertainty in the supply chain due to weather. As many of the villages are not connected to a formal grid, diesel generators are traditionally employed to supply electricity, and this has significant implications from both an economic and energy security perspective. Economically, this is important considering the high cost of purchasing and transporting fuel to these remote regions. When assessed from an energy security perspective, the dependability of supply chains to village locations directly impacts electricity availability.

As a means offsetting diesel generation using local resources, this study is intended to identify potentially new hydropower development sites within untapped stream-reaches. This study builds off of a 2014 United States Department of Energy's (DOE) funded study, conducted by Oak Ridge National Laboratory (ORNL), which evaluated the new stream-reach development (NSD) resource potential of more than 3 million U.S. streams. ${ }^{[3]}$ As a part of that NSD study ORNL coordinated with the Alaska Energy Authority (AEA) and the U.S. Army Corps of Engineers (USACE) to assess NSD potential of stream-reaches in Alaska lacking existing hydropower infrastructure. Specifically, the NSD study reviewed existing siting and feasibility reports of the 2,200 possible sites in Alaska, 437 of which passed that screening and were deemed potentially feasible.

Figure 1 shows the locations of native villages, existing hydropower plants, and the 437 feasible sites as determined from the 2014 study $^{[3]}$. The total potential for the 437 sites is $4,723 \mathrm{MW}$.

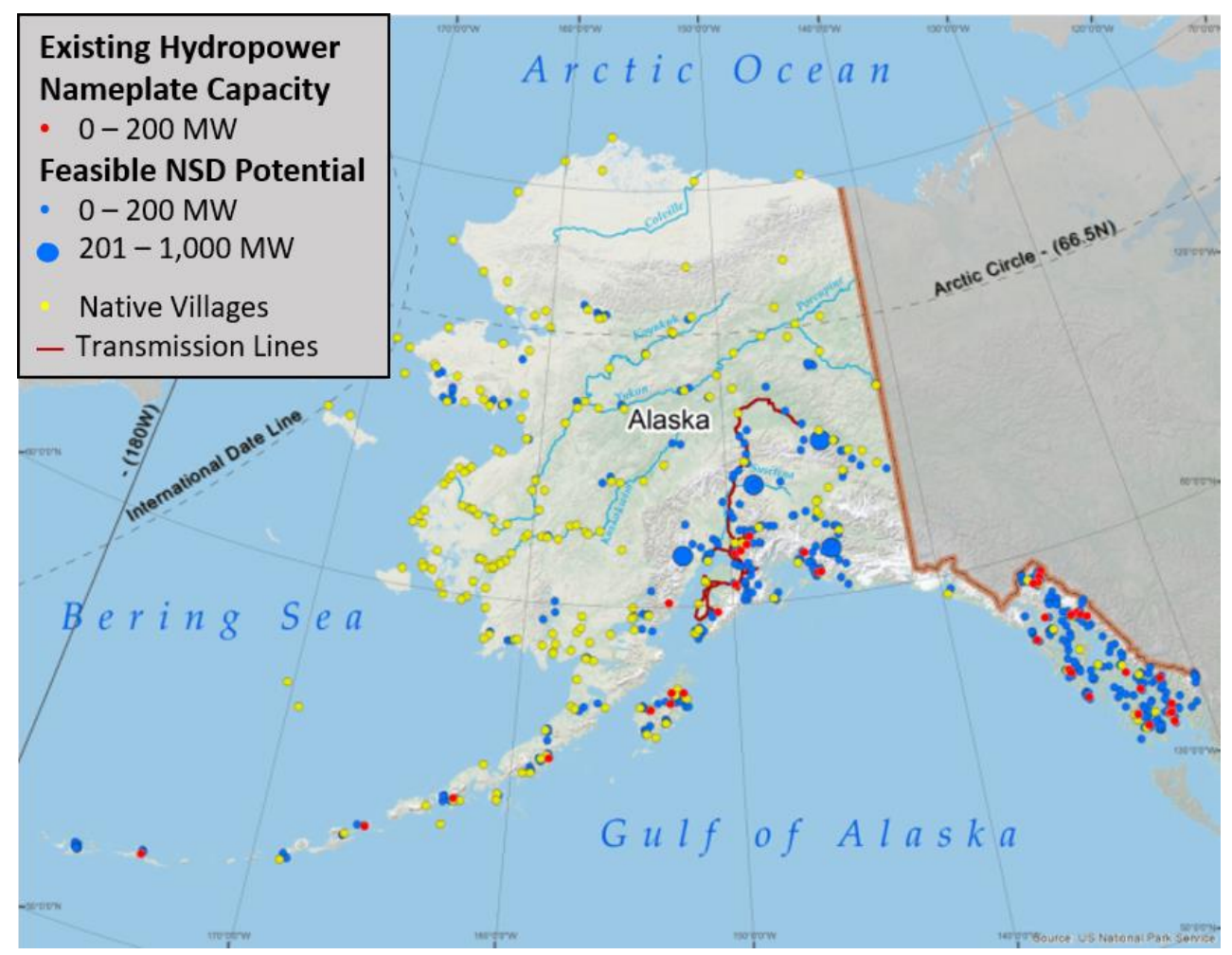

Figure 1. Feasible Hydropower Potential and Native Village Locations 


\section{METHODS}

This section will discuss the methods and assumptions used to conduct the screening analysis.

\subsubsection{Data Processing}

The Bureau of Indian Affairs (BIA) provided names and geospatial point locations of the 225 Alaska Native villages to allow assessment of the viability of hydroelectric generation. Village population data were acquired from the 2010 Demographic Profile developed by the United States Census Bureau ${ }^{[6]}$. Geospatial data processing methods were implemented with ArcMap 10.2 software to calculate the proximity of BIA's Alaska village locations to the hydropower sites identified in the 2014 study and create relationships among the respective attributes. Village-level statistics (e.g. diesel consumption, fuel costs, and power generation) were provided by AEA using data from Alaska's Power Cost Equalization (PCE) program. Alaska's PCE program provides economic assistance to communities and residents in rural areas of the state where, in many instances, the kilowatt-hour charge for electricity can be three to five times higher than the average rate of urban Alaskan areas ${ }^{[1]}$. Of the 225 native villages locations provided by BIA, 171 participate in the PCE program. As a requirement of the PCE program, participating utilities must file monthly reports with AEA to receive payment. These reports are available online and include statistics on diesel volume (gallons) used, cost, price per gallon, and kilowatt-hours produced and purchased ${ }^{[4]}$. For some villages, 2016 data were not available due to late reporting or lack of program participation that year; in such cases, the most recent full fiscal year's data are considered. If data are reported from a larger community that supplies power to the native village, those data are included as proxy.

Data processing assumptions used for this study included:

- Only the 171 PCE participating villages are considered in the analysis due to data availability and to ensure data uniformity.

- Fiscal year 2016 data are used, if available. If data are not available for that year, the most recent full fiscal year's data are included.

- PCE data prior to FY16 were used for 6 villages or 3.5\% of total.

- If village data are reported as part of a larger community, that community's fuel, energy, and cost data are used as proxy.

- PCE data for larger communities were used as a proxy for 13 villages or $7.6 \%$ of total.

- Only the closest village to each hydropower site is considered in this analysis.

\subsubsection{Hydropower Potential Estimates}

Estimates for the technical hydropower potential are calculated for each site assuming a $50 \%$ capacity factor (ratio of average power generated to rated peak power) and using the capacity from the 2014 NSD report ${ }^{[3]}$. The potential annual $\mathrm{kWh}$ generation from the 2014 NSD study was compared with the annual $\mathrm{kWh}$ consumed by a village as reported to the PCE program to calculate the percent diesel offset that the potential hydropower facility would provide. In many cases, the technical potential generation from hydropower exceeded the energy demand from associated villages. Potential hydropower capacity was reduced for those sites assuming the project would be developed exclusively to meet, but not exceed, energy demands for the closest villages to the site(s). These village-tailored capacity values are the usable hydropower potential. Conceptually, one hydropower project could provide power to multiple villages or multiple projects could 
provide power to a single village; however, further studies are needed to elucidate hydropower potential under these scenarios, and therefore were not considered as part of this study.

Hydropower potential estimate assumptions used for this study included:

- Seasonal variability was not considered when comparing hydropower and diesel generation, to determine the hydropower capacity and diesel offset.

- Typically, yearly averaged hydraulic heads and flow rates were used from 2014 NSD reports.

- To calculate potential hydropower generation, a 50\% capacity factor is assumed.

- If a hydropower site has a technical potential capable of generating more $\mathrm{kWh}$ than needed for a village, the usable project capacity is computed to meet the actual energy demand of the village for $100 \%$ elimination of diesel generation, without considering seasonal variability.

- Multiple villages receiving power from one site was not considered.

- Multiple sites providing power to one village was not considered.

\subsection{Cost and Savings Projections}

To examine the long-term savings in diesel costs at each village and evaluate the economic viability of an investment in hydropower, each hydropower site was assumed to be built for a 50-year lifespan and would provide an equivalent of 50 years of diesel fuel offset. In addition to data from PCE reports, AEA provided fuel projection data for the delivered price of diesel to PCE members through the year 2040.

AEA has developed a model to correlate specific rural diesel fuel prices to published indices of crude oil prices which takes into account the many factors and costs of transporting diesel fuel from the refinery to a specific community. ${ }^{[5]}$ AEA's fuel price projection model uses regression analysis to estimate what the price of diesel will be in a community based on the U.S. Energy Information Administration (EIA) Brent crude oil price projections ${ }^{[8]}$ and historic PCE utility invoices. To estimate future diesel prices for the 50year project lifespan beyond 2040, a flat 3\% inflation rate was applied to the 2040 AEA projection for the years 2041-2066 at AEA's suggestion. With yearly fuel prices computed for the full 50-year project lifespan (i.e. 2017-2066), the net present value was calculated using a discount rate of 3\%. ${ }^{[7]}$ The present value (PV) of 50-year fuel cost (assumed to represent the 50-year savings from hydropower) can be used in future sitespecific economic analysis to in an initial evaluate the economics of hydropower development.

Cost and savings projection assumptions used for this study included:

- Cost of project development and operation not considered under this study.

- A hydropower project lifespan is assumed to be 50 years.

- When projecting fuel costs beyond 2040, a $3 \%$ inflation rate was used.

- When computing net present value, a $3 \%$ discount rate was used.

\subsection{Feasibility Filters}

Seven filters were used to determine the feasibility of a potential hydropower site, three static filters were used, including: (1) the closest village to each hydro site (Filter 3), (2) whether hydropower has already been considered for construction (Filter 4), and (3) if underwater cable would be necessary for transmission (Filter 5). The other four filters are dynamic and are user-controlled with default input values. Two of these 
filters remove villages too far north (Filter 1) or too far away from potential sites (Filter 6). The other two user-controlled filters aim to screen out villages where the population is too small (Filter 2) or where the hydropower potential would not offset a defined percentage of diesel usage (Filter 7). Latitude, distance from site, population and offset were established as dynamic filters, which allowing future users with various project goals and budgets to evaluate hydropower potential based on the parameters best suited for the application. All seven filters are defined below:

- Filter 1 - "North of maximum latitude limit?"

○ This filter excludes from consideration villages too far north where hydro development is likely not feasible due to unfavorable weather conditions.

$\circ$ The default input value is set to $63^{\circ} \mathrm{N}$ yet can be modified at user discretion.

- Filter 2 - "Village meets minimum population?"

○ This filter excludes from consideration villages with populations smaller than a specified value.

- The default input value is set to 25 residents yet can be modified at user discretion.

- Filter 3 - "Closest village to hydropower site?"

- This filter excludes from consideration villages that are not the closest village to a specific hydropower site.

- The Alaska NSD assessment identified the closest feasible site to each village. In the case where one site is the closest to multiple villages, only the closest village was considered since it would have less transmission line costs.

- Filter 4 - "Existing hydropower development?"

- This filter excludes from consideration sites that have already been developed.

- AEA, PCE reporting data, and FERC licenses were used to confirm existing hydropower facilities.

- Filter 5 - "Underwater cable required?"

$\circ$ This filter excludes from consideration villages where the closest identified NSD site is across a body of water.

- Distance values from the 2014 NSD study did not account for geographical barriers, such as mountains or water bodies. If a body of water exists between village and NSD site, underwater cable would be required. As underwater cable increases the cost of transmission, those situations were excluded.

- Filter 6 - "Transmission line exceeds maximum distance?"

- This filter excludes from consideration villages that exceed a maximum distance from a potential site and would, therefore, have large transmission line length and costs.

$\circ$ The default input value is 5 miles yet can be modified at user discretion.

- Filter 7 - "Hydropower provides significant diesel offset?"

- This filter excludes from consideration cases where potential hydropower development would offset a minimal portion of a village's total diesel usage.

○ The default input value is $50 \%$ offset yet can be modified at user discretion.

- Additionally, this filter removes from consideration situations where a village did not use diesel generation for power.

The villages that pass all seven filters were considered the best candidates for further analysis. 


\section{RESULTS AND NEXT STEPS}

Many sites were close to meeting all filters but failed to meet one or more criteria. While these criteria leveraged expert opinion from AEA staff and are based on sound engineering judgment, it is difficult to know what site-specific features may prove advantageous or detrimental to hydropower development or how certain technological or economic conditions may change in the future.

Of the 171 villages analyzed, only eleven passed each of the seven filters and offer a potential for hydropower development, subject to further analysis. To meet the energy demand of these villages, hydropower projects could be developed to provide a combined usable capacity of $1.25 \mathrm{MW}$ and 5,488 MWh of annual power generation. Without considering village energy demand, these eleven sites have a combined technical capacity of $2.95 \mathrm{MW}$ and annual generation of 12,934 MWh based on ORNL's previous 2014 NSD study. This hydropower potential could reduce the collective diesel usage by 435,000 gallons a year which amounts to a PV of 50-year diesel savings totaling more than \$57 million.

By passing all filters, these villages and sites have been identified as the best candidates for further sitespecific analysis. Figure 2 identifies the eleven villages and sites identified for future hydropower development. Table 1 includes the data for each of the eleven villages and hydropower sites. Additional economic analysis could be conducted to further assess the feasibility of these eleven identified opportunities and reassess other sites which did not pass initial screening. 


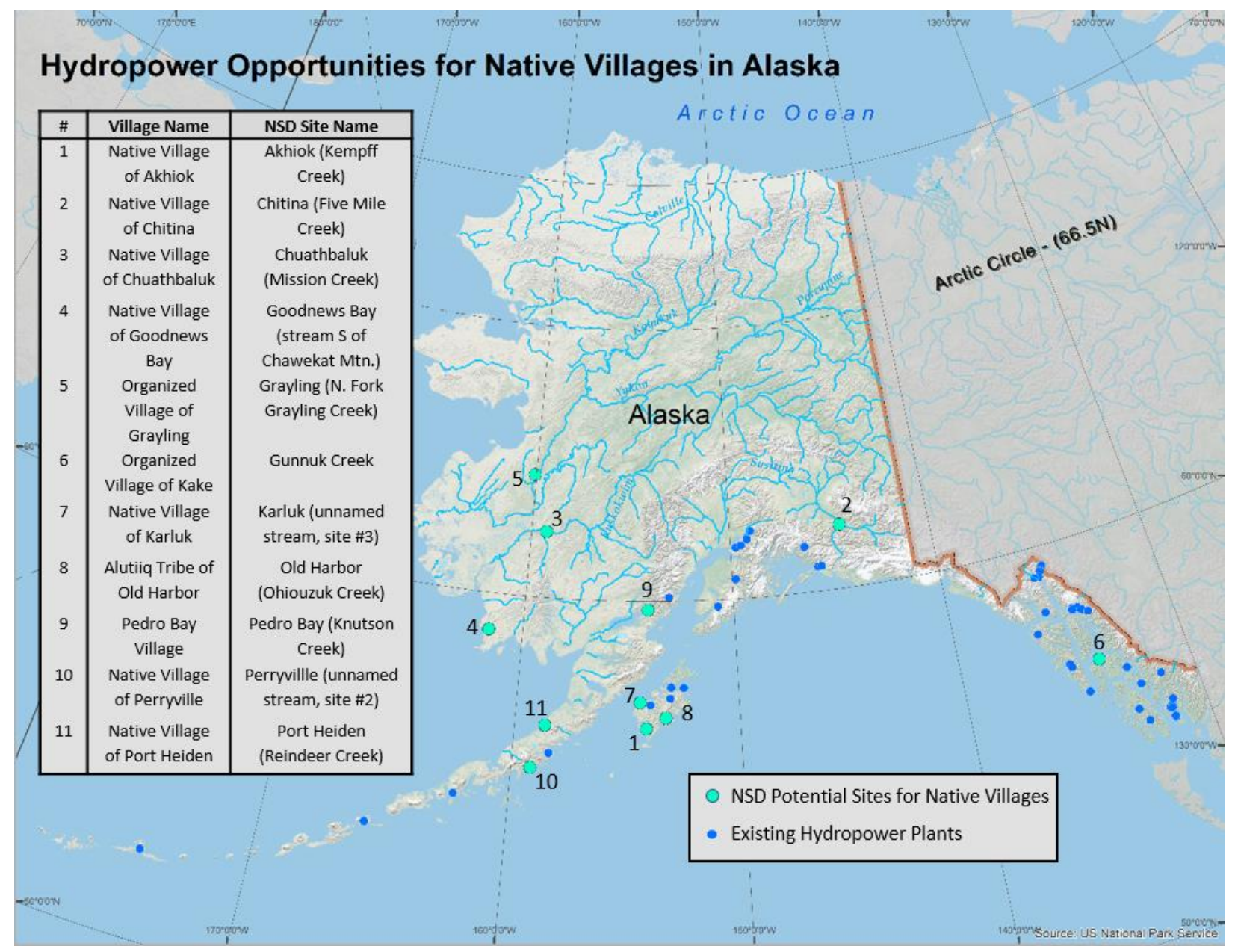

Figure 2. Hydropower Sites Passing Screening 
Table 1. Villages and Sites Meeting All Filter Criteria

\begin{tabular}{|c|c|c|c|c|c|c|c|c|c|}
\hline \multirow[b]{2}{*}{ Village Name } & \multirow[b]{2}{*}{ Site Name } & \multirow[b]{2}{*}{ Population } & \multirow[b]{2}{*}{$\begin{array}{c}\text { Distance } \\
\text { between Site } \\
\text { and Village } \\
\text { (miles) }\end{array}$} & \multicolumn{2}{|c|}{ Technical Stream Potential } & \multicolumn{2}{|c|}{ Estimated Village Need } & \multirow[b]{2}{*}{$\begin{array}{c}\% \text { Diesel } \\
\text { Consumption } \\
\text { Offset }\end{array}$} & \multirow[b]{2}{*}{$\begin{array}{c}\text { Estimated } \\
\text { PV of } 50 \\
\text { Year Savings } \\
\text { (Million\$) } \\
\end{array}$} \\
\hline & & & & $\begin{array}{c}\text { Potential } \\
\text { Capacity } \\
(\mathbf{k W})\end{array}$ & $\begin{array}{c}\text { Potential } \\
\text { Annual } \\
\text { Generation } \\
\text { (kWh) }\end{array}$ & $\begin{array}{c}\text { Capacity } \\
\text { Needed }(k W)\end{array}$ & $\begin{array}{c}\text { Annual } \\
\text { Generation } \\
\text { Needed } \\
(\mathbf{k W h})\end{array}$ & & \\
\hline $\begin{array}{c}\text { Native Village of } \\
\text { Akhiok }\end{array}$ & Akhiok (Kempff Creek) & 81 & 1.8 & 137 & 600,060 & 65 & 284,843 & 100 & 4.4 \\
\hline $\begin{array}{l}\text { Native Village of } \\
\text { Chitina }\end{array}$ & $\begin{array}{c}\text { Chitina (Five Mile } \\
\text { Creek)* }\end{array}$ & 116 & 5.0 & 300 & $1,314,000$ & 102 & 445,030 & 100 & 4.8 \\
\hline $\begin{array}{c}\text { Native Village of } \\
\text { Chuathbaluk }\end{array}$ & $\begin{array}{c}\text { Chuathbaluk (Mission } \\
\text { Creek) }\end{array}$ & 134 & 3.2 & 125 & 547,500 & 57 & 249,634 & 100 & 3.2 \\
\hline $\begin{array}{c}\text { Native Village of } \\
\text { Goodnews Bay }\end{array}$ & $\begin{array}{c}\text { Goodnews Bay (stream S } \\
\text { of Chawekat Mtn.) }\end{array}$ & 259 & 4.9 & 85 & 372,300 & 85 & 372,300 & 56 & 3.2 \\
\hline $\begin{array}{c}\text { Organized Village of } \\
\text { Grayling }\end{array}$ & $\begin{array}{c}\text { Grayling (N. Fork } \\
\text { Grayling Creek) }\end{array}$ & 191 & 0.8 & 230 & $1,007,400$ & 138 & 605,543 & 100 & 7.7 \\
\hline $\begin{array}{c}\text { Organized Village of } \\
\text { Kake }\end{array}$ & Gunnuk Creek & 626 & 1.3 & 300 & $1,314,000$ & 300 & $1,314,000$ & 57 & 10.9 \\
\hline Native Village of Karluk & $\begin{array}{c}\text { Karluk (unnamed stream, } \\
\text { site \#3) }\end{array}$ & 43 & 2.9 & 180 & 788,400 & 45 & 199,228 & 100 & 2.1 \\
\hline $\begin{array}{c}\text { Alutiiq Tribe of Old } \\
\text { Harbor }\end{array}$ & $\begin{array}{c}\text { Old Harbor (Ohiouzuk } \\
\text { Creek) }\end{array}$ & 213 & 1.1 & 296 & $1,296,480$ & 191 & 838,064 & 100 & 6.7 \\
\hline Pedro Bay Village & $\begin{array}{c}\text { Pedro Bay (Knutson } \\
\text { Creek) }\end{array}$ & 47 & 2.1 & 100 & 438,000 & 44 & 193,314 & 100 & 3.2 \\
\hline $\begin{array}{c}\text { Native Village of } \\
\text { Perryville }\end{array}$ & $\begin{array}{l}\text { Perryvillle (unnamed } \\
\text { stream, site \#2) }\end{array}$ & 101 & 3.6 & 850 & $3,723,000$ & 109 & 476,422 & 100 & 3.8 \\
\hline $\begin{array}{c}\text { Native Village of Port } \\
\text { Heiden }\end{array}$ & $\begin{array}{l}\text { Port Heiden (Reindeer } \\
\text { Creek) }\end{array}$ & 114 & 4.9 & 350 & $1,533,000$ & 116 & 509,409 & 100 & 7.4 \\
\hline & Total & 1,925 & 2.9 (avg) & 2,953 & $12,934,140$ & 1,253 & $5,487,787$ & 92.1 (avg) & 57.7 \\
\hline
\end{tabular}

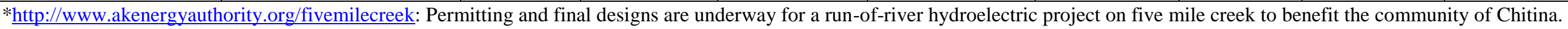

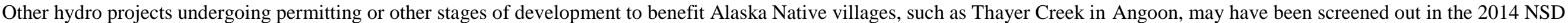
report study on which this analysis expands upon. 


\section{WORKS CITED}

[1] Alaska Energy Authority. (2014). Power Cost Equalization Program Guide. Anchorage, Alaska. Retrieved from:

http://www.akenergyauthority.org/Content/Programs/PCE/Documents/PCEProgramGuideJuly29 2014EDITS.pdf

[2] Bureau of Indians Affairs. (2016). Email communication, December 2016, between ORNL Dr. Hadjerioua Boualem and Bureau of Indians Affairs, Mis. Jessica Rodriguez, Cartographer.

[3] Kao, S.-C., McManamay, R., Stewart, K., Samu, N., Hadjerioua, B., DeNeale, S., et al. (2014). New Stream-reach Development: A Comprehensive Assessment of Hydropower Energy Potential in the United States. Washington D.C.: U.S. Department of Energy.

[4] Melendez, Alejandra. (2014) Power Cost Equalization Program Dataset: Data Cleaning \& Imputation Methodology Notes. Anchorage: University of Alaska Anchorage. Retrieved from: https://akenergygateway.alaska.edu/static/public/documents/PCE_DataCleaningImputation_Meth odologyNotes_09172014.pdf

[5] Pride, D., Snodgrass, M., Scott, A. (2015). Correlating Community Specific Rural Diesel Fuel Prices with Published Indices of Crude Oil Prices, And Potential Price Projection Applications. Fairbanks: Alaska Center for Energy and Power. Prepared for Alaska Energy Authority. Retrieved from: http://www.akenergyauthority.org/Content/Programs/RenewableEnergyFund/Documents/Round \%209/RuralFuelModelReportFinalDraft.pdf

[6] U.S. Census Bureau. (2010). Community Facts. Retrieved from American Fact Finder.

[7] U.S. Department of Energy. (2017). 2017 Discount Rates. Retrieved from: https://energy.gov/sites/prod/files/2017/05/f34/2017discountrates

[8] U.S. Energy Information Administration. (2014). Annual Energy Outlook 2014. Washington D.C.: U.S. Department of Energy. Retrieved from: www.eia.gov/forecasts/aeo 